\section{REMOVABLE MOUNTING OF THE ROLLING MACHINES' WORKING ROLLS}

JAN HLAVAC ${ }^{1}$, MARTIN VOLEJNICEK ${ }^{2}$, PETR GAVENDA ${ }^{2}$, DAVID VYDRZEL ${ }^{1}$, JIRI DEKASTELLO ${ }^{1}$, KAREL GLATZ

${ }^{1}$ Department of Machine design, Faculty of Mechanical Engineering, University of West Bohemia, Plzen, Czech Republic; ${ }^{2}$ Smeral Brno a.s., Brno, Czech Republic

DOI : 10.17973/MMSJ.2021_03_2021002

jhlavac@kks.zcu.cz

The work is focused on the design solution of fixing the exchangeable working rolls into cross-wedge rolling machine. The tools are clamped to the cylinders. In case of technology change, the tools must be replaced. Tools can be changed directly on the machine, this is a non-productive time. Another way to change tools is to replace entire cylinders. The diameter of the rollers is large, so the rollers themselves cannot be pulled out through the side hole, as is the case with a rolling mill. There are several ways to connect the middle part of the cylinders to the pins located in the stands. The work compares connections with a lid and a square or cylindrical shaft and variants in a singlesided extension able shaft with a conical or spherical surface. The aim of the work is to compare the stiffness of connection methods.

KEYWORDS

Rolling Machine; Cross-wedge Rolling; CAE; Shaft Connection; Stiffness

\section{INTRODUCTION}

Cross wedge rolling machines (see Fig. 1) are used for production of rotational forging from cylindrical blocks or rods.

Cross wedge rolling machines (see Fig. 1) are used for production of rotational forging from cylindrical blocks or rods. There are several possible design variants of machine. This article deals with rolling mill with two working rolls [Hladky 1969]. Next common variant is a machine with flat tools [Malinkin 1972, Tomczak 2018]. Other variant are not common [Pater 2014]

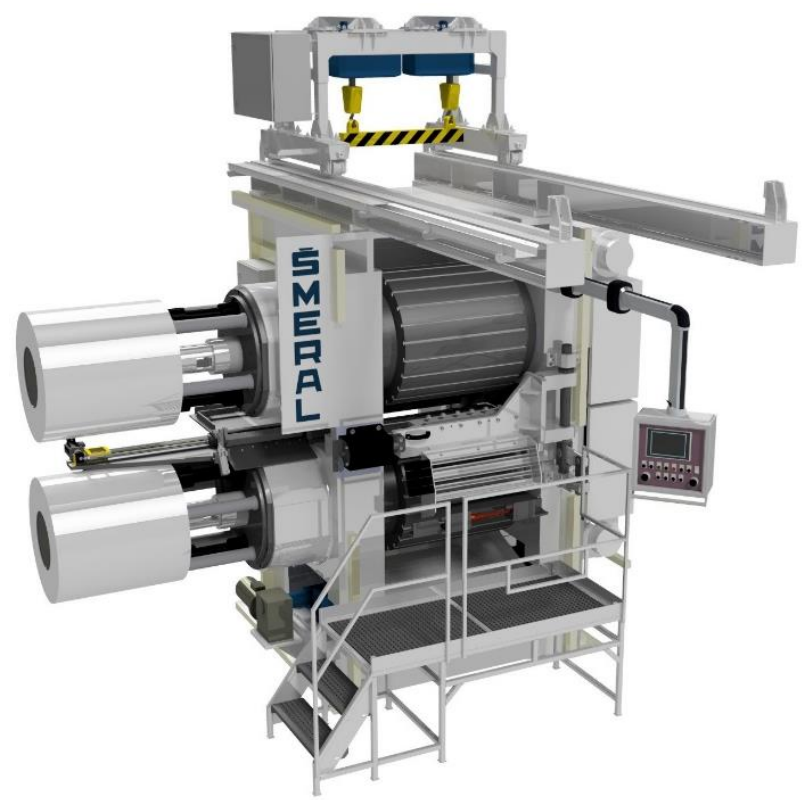

The working rolls are supported on both ends by assembly of roller bearings. With standard rolling mill it is possible to use sliding bearings [Meingast 2020]. It is also possible to design rolling machine with tools on overhanging ends [Normaley 1973].

Cross-wedge rolling is a high productive technology process with full automation. It takes less than $10 \mathrm{sec}$ to finish duty cycle. Because the machine itself and tool (complicated cylindrical shape) are expensive, it is important to shorten non-productive times [Bartosek 2011].

The Smeral Brno a.s. company gradually developed and improved individual roller bearing solutions for cross wedge rolling machines. The results of performed analytical calculations and results of the measured displacements on the manufactured machines differs for different proposals. Within project FV10578 virtual simulation of rolling machine was performed and results differences were described. New findings were promoted to structural design of new machines with aim to improve stiffness and subsequently it's precision.

The old one machines were produced with fixed working rolls. It was solution with high stiffness and precision. But it took hours (non-productive time) to replace tools by new ones. Therefore current working rolls can be replaced in the machine. The original fixed working roll was divided into Drive Shaft, Working Roll and Support Shaft [Hlavac 2018].

Comparison of design alternatives of fixing the working rolls inside in the machine is the main goal of this work.

\section{DESIGN ALTERNATIVES OF FIXING THE WORKING ROLLS}

As the working rolls carry the tool there are several requirements they must meet.

Requirement on the working rolls:

- Sufficient strength (radial and torsional loads).

- High stiffness (small deformations = process stability and production accuracy) [Liping 2020].

- High accuracy position.

- Thermal stability (cooling or preheating can be used).

- Low costs.

All of requirements mentioned above must be met even with exchangeable working rolls.

There are four alternatives of how to fix the working rolls inside of machine described within this work. Design alternatives of fixing the working rolls can be divided into two different principles:

- A working roll mounted in an open seats and fixed by clamps. - A working roll gripped with conical or ball seat.

\subsection{Open seats and clamps}

There are two alternatives of working roll mounted in an open seats and fixed by clamps. The difference is rolls' ends shape. The first rolls' end cross section is circle (see fig. 2) and second is square (see fig. 3) [Hladky 1991, Baoshou 2012]. 

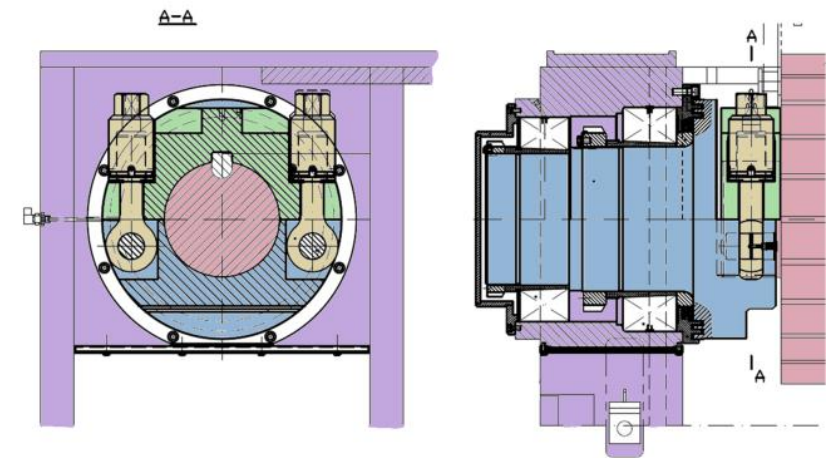

Figure 2. Roll mounting in an open seats circle cross section: purple stand; red - roll; blue - support shaft; green - clamp; ochre - fixing bolt (Smeral Brno a.s.)

Alternative with circle cross section use key to prevent the roll to slip in its seat. It is important on drive side because bottom and upper roll must be precisely synchronized. Precise roll synchronisation is important due to technology process stability. There is no need for key usage due to square roll end with second variant (see Fig. 3).

Both support shafts are axially fixed within machine stand. There are two roll bearings on both of support shafts. Rolls can be removed or placed back into machine after remove of clamps.
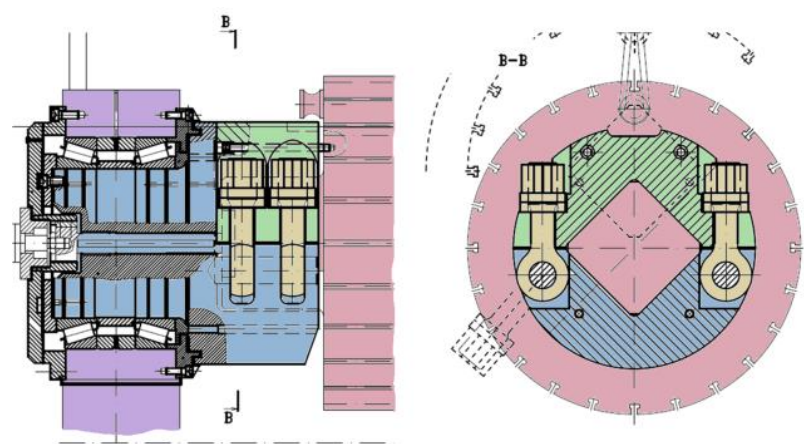

Figure 3. Roll mounting in an open seats square cross section: purple stand; red - roll; blue - support shaft; green - clamp; ochre - fixing bolt (Smeral Brno a.s.)

\subsection{Conical or ball seat}

There are two alternatives of working roll gripped between seats. The first one is with conical seat (see Fig. 4) and second with ball seat (see Fig. 5). Both variant differs only in seat shape. The seat is a bronze insert within the working roll (on both sides).

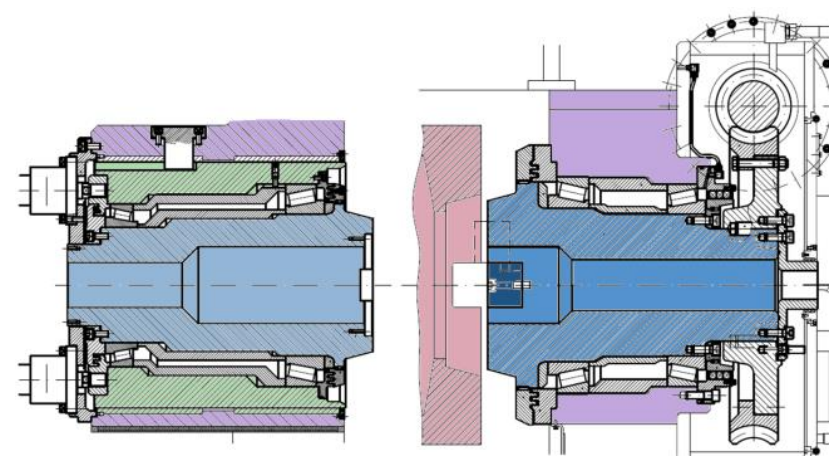

Figure 4. Roll gripped with conical seat, support and retractable shaft (left) and drive side support shaft (right): purple - stand; red - roll; blue - support shaft and key; green - retractable shaft (Smeral Brno a.s.)

There is need to add a retractable shaft into machine design to allow to remove or to place back of the working roll into the machine. The retractable shaft is situated on non-drive side. It is supported within slide bearing and it is operated by hydraulic motor.

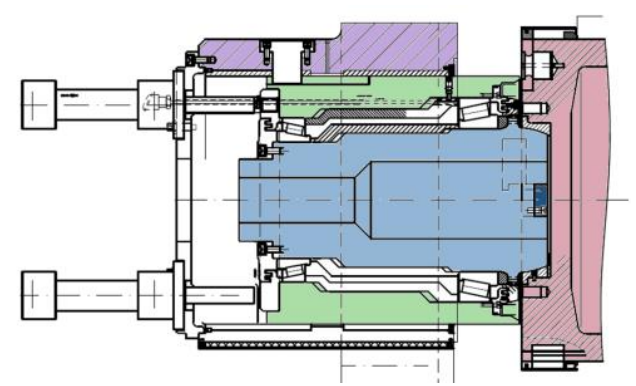

Figure 5. Roll gripped with ball seat: purple - stand; red - roll; blue support shaft and key; green - retractable shaft (Smeral Brno a.s.)

\subsection{Comparison of expected properties}

There were several different expected properties for design alternatives:

- There is need for key to secure synchronous rotation of working rolls (with exception of open seat square cross section variant).

- There is a need to enforce grip force of the working roll. This force will additionally load machines' frame.

- Centring of the working roll with machines' shafts is more precise for variants with conical or ball seat.

- Stiffness of the working roll may differ according to clamp position for variants with mounting in an open seat.

- The strength of the design proposal is sufficient as the stiffness is main goal. There are known issues with coupling [Domazet 2014].

- Time needed to replace of the working roll is shorter for variants with conical or ball seat.

\subsection{Goals of research}

The main goal of research is to determine the stiffness of design variants. To answer a questions:

- Are variants with gripped roll equivalent to variants with seat and clamp?

- Which seat is better - conical or ball shape?

\section{VIRTUAL SIMULATION}

Finite element method (FEM) was used to realize the virtual simulation. As long is the research focused onto stiffness of connection of the working roll there is no need to simulate whole machine. Virtual model consists only of an upper part of machines' frame (see Fig. 6). There is also no drive mechanism within a model.

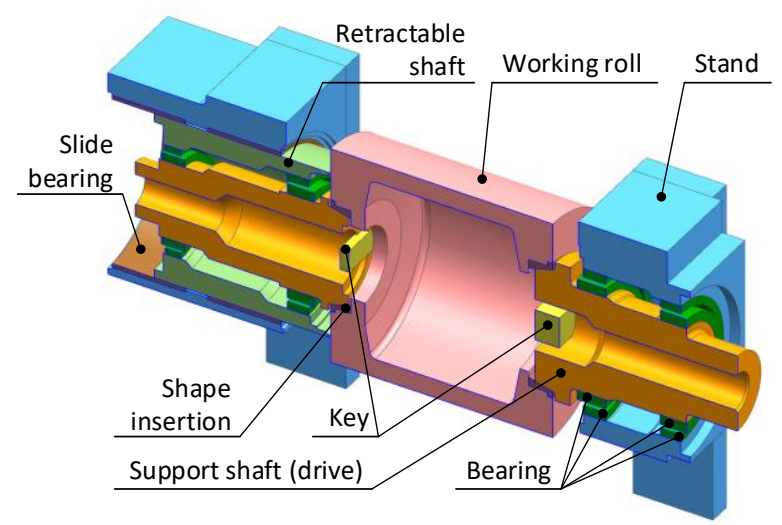

Figure 6. Model for virtual simulation 


\subsection{Mesh model}

The mesh model consists of 3D meshs defining for 3D bodies and auxiliary $1 \mathrm{D}$ elements (for example in a connection with bearing). The 3D mesh is defined for two materials - steel (mass density $7.829 \mathrm{e}-06 \mathrm{~kg} / \mathrm{mm}^{3}$; Young's modulus $206.94 \mathrm{GPa}$; Poisson's ratio 0.288 ) and bronze (mass density $8.852 \mathrm{e}-06 \mathrm{~kg} / \mathrm{mm}^{3}$; Young's modulus 103.4 GPa; Poisson's ratio 0.34). Bronze is defined for bronze bushings and for retractable shaft. The mesh has been refined in contact locations.

There is a pair of spherical or tapered bearings on both support shafts. There are no 3D models of bearings within a model. Those bearings are substituted by 1D spring model with defined radial and axial stiffness (see Tab. 1). Inner and outer bearings' races were keep within a model as a 3D model to preserve connection between shaft and stand (see Fig. 7).

\begin{tabular}{|c|c|c|}
\hline Bearing & $\begin{array}{c}\text { Radial stiffness } \\
{[\mathrm{MN} / \mathrm{mm}]}\end{array}$ & $\begin{array}{c}\text { Axial stiffness } \\
{[\mathrm{MN} / \mathrm{mm}]}\end{array}$ \\
\hline SKF 23084CAK/W33 & 1.36 & 0.83 \\
\hline SKF 23092CAK/W33 & 1.27 & 1.3 \\
\hline $\begin{array}{c}\text { Timken } \\
\text { NP771673/NP725758 }\end{array}$ & 6.25 & 0.98 \\
\hline $\begin{array}{c}\text { Timken } \\
\text { M270744/M270710 }\end{array}$ & 7.52 & \\
\hline \begin{tabular}{l} 
M270749/M270710 \\
\hline
\end{tabular}
\end{tabular}

Table 1. Stiffness values for used roller bearings

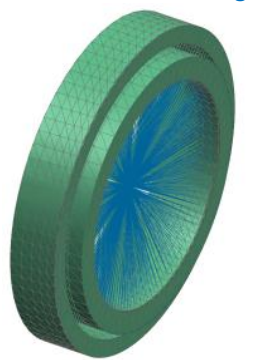

Figure 7. Mesh model of bearing (Inner and Outer races as 3D mesh; 1D mesh to connect spring with rings)

\subsection{Boundary conditions}

\subsubsection{Contacts}

Demonstration of models' contact is performed with roll gripped with conical seat model (see Fig. 8).

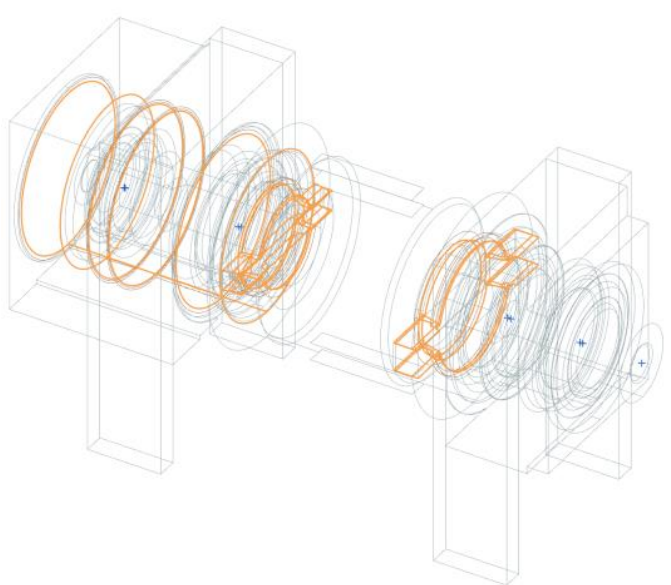

Figure 8. Wired model with highlighted contact surfaces
Bodies that touch in the real machine but no contact is defined for them are for simplification firmly connected using the Mesh Mating function (network connection - primarily node-to-node connection).

Coefficient of friction was set same for all contact surfaces with value 0.1 although there are dry pairs steel to steel or lubricated pair steel to lead bronze in model.

\begin{tabular}{|c|c|c|}
\hline Contact pair & $\begin{array}{c}\text { Friction } \\
\text { coef. }\end{array}$ & $\begin{array}{c}\text { Offset } \\
\text { value }\end{array}$ \\
\hline $\begin{array}{c}\text { Retractable shaft } \mathrm{x} \\
\text { Slide bearing }\end{array}$ & 0.1 & 0 \\
\hline $\begin{array}{c}\text { Support shaft } \mathrm{x} \text { Shape } \\
\text { insertion }\end{array}$ & 0.1 & 0 \\
\hline Key $\times$ Working roll & 0.1 & -0.05 \\
\hline
\end{tabular}

Table 2. Contact parameters

\subsubsection{Loads}

All simulations were performed for two load cases.

The first one is fully assembled model with all preloads (clamps' bolts or retractable shaft) and gravity. Preload force of clamps' bolts is $1.5 \mathrm{MN}$. Preload force of retractable shaft is $20 \mathrm{kN}$.

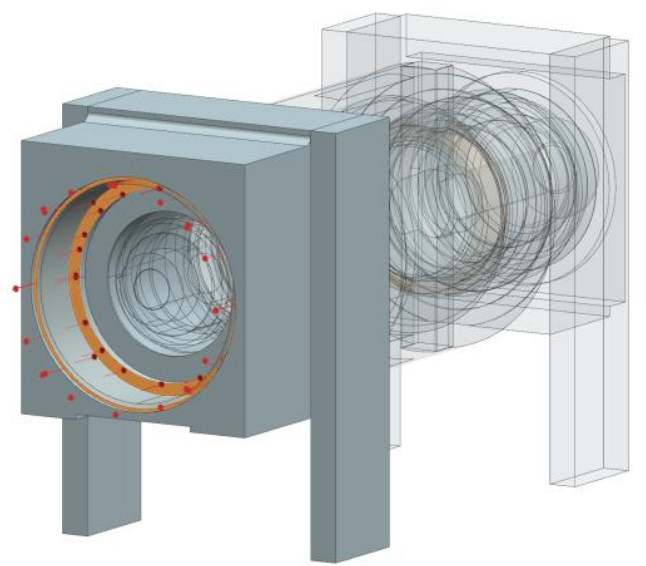

Figure 9. Application of preload force of retractable shaft

Second load set consist of the whole first one plus workload. Value of workload is $700 \mathrm{kN}$ and it acts with torque $20 \mathrm{kNm}$ therefore the line of this force is skew to rolls' axis. The workload is acting from down to up. The relation between force and moment is $M=F \cdot e$. It is important to find the moment arm (see Fig. 10).

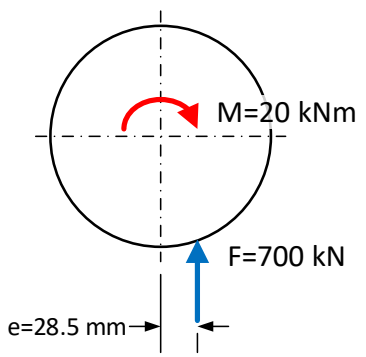

Figure 10. Moment arm of workload

For a models with clamp there are three possible orientations of clamp and force orientation. All those position are subjected to simulation. It means there are six solutions for every model with clamp. 

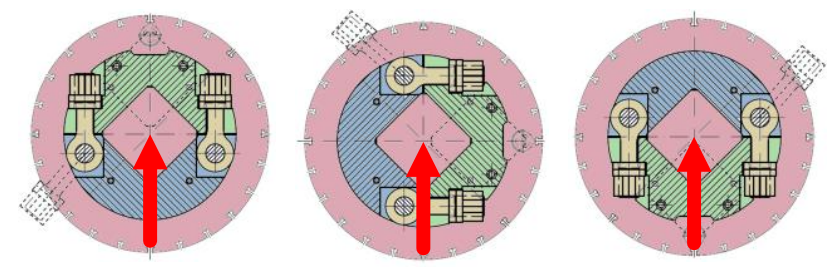

Figure 11. Moment arm of workload

There is similar situation for model with gripped roll - there is a key between support shaft and the working roll. Vertical and horizontal position of key was simulated only.

It is 20 different simulations in total to compare.

\subsubsection{Constraints}

All bottom faces of stands are fully fixed (i.e. for displacement and rotation).

End of drive side support shaft has fixed rotation on its axis because there is a moment.

\section{RESULTS}

Comparison is aimed to stiffness only. Therefore only vertical displacement is taken into account. There is an example of graphical results interpretation (see Tab. 3 ) in next tables.

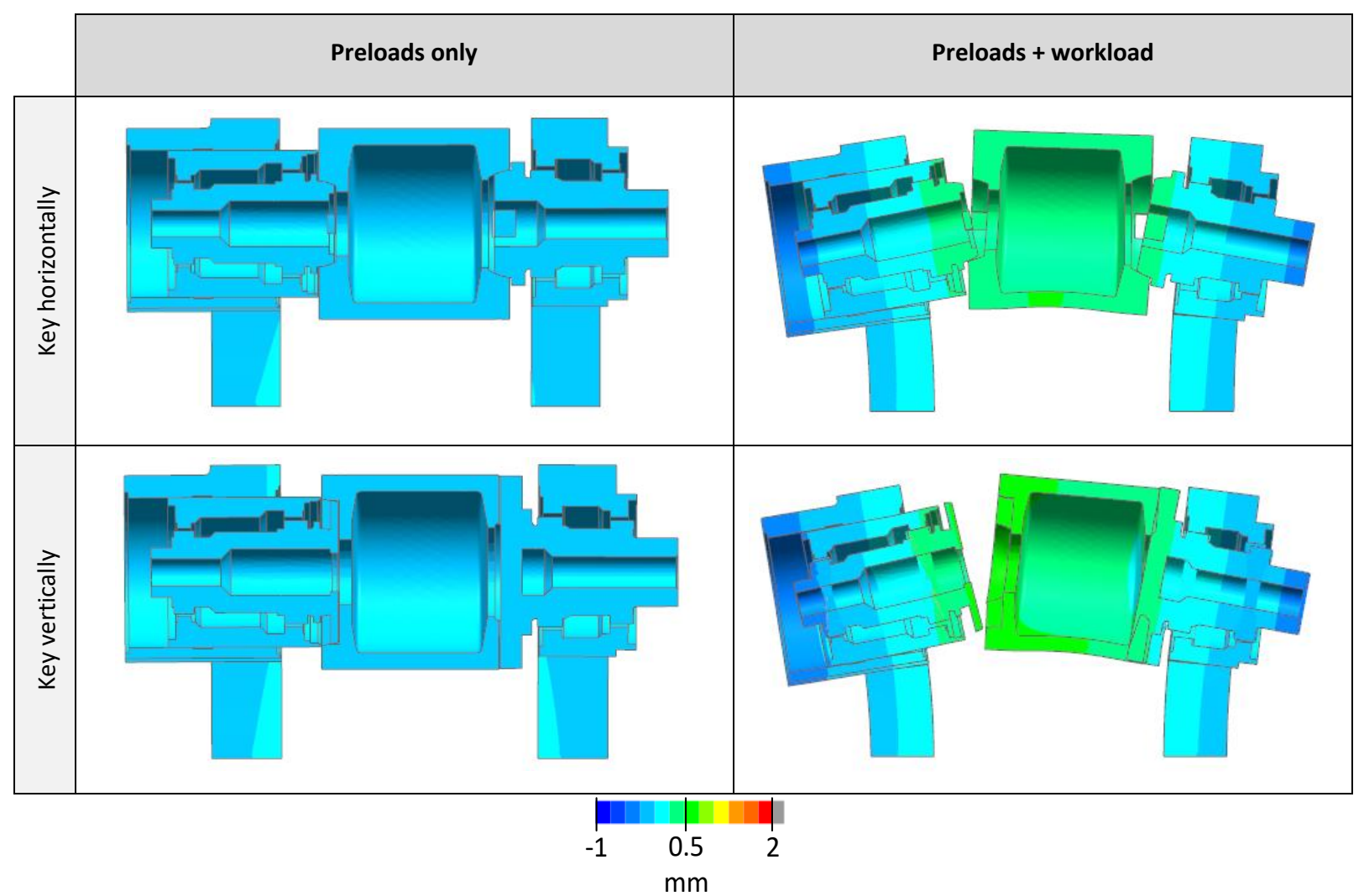

Table 3. Vertical displacements' results - Roll gripped with ball seat

\subsection{Results' mining}

Especially for variants with gripper working rolls it is important to read results precisely because the assembly is complex. The aim was to find weaknesses of design whether it is retractable shaft or bearings or interface between support shaft and working roll. Therefore schematic description of what, where and how to read results was prepared (see Fig. 12).

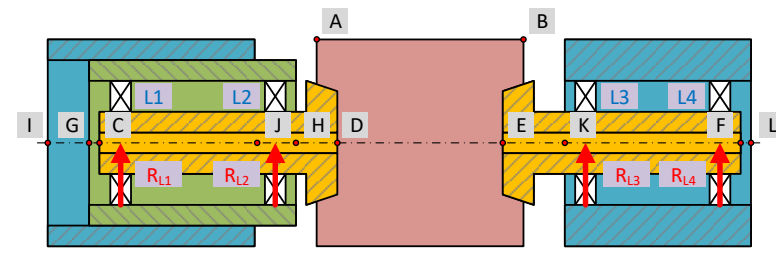

Figure 12. Schematic model How to read results

Description of individual points (see schematic model): A - upper left edge of the working roll $\mathrm{B}$ - upper right edge of the working roll
C- left centre of left support shaft

D - right centre of left support shaft

$E$ - left centre of right support shaft

$\mathrm{F}$ - right centre of right support shaft

$\mathrm{G}$ - left centre of retractable shaft

$\mathrm{H}$ - right centre of retractable shaft

I- left centre of the left housing

$\mathrm{J}$ - right centre of the left housing

$\mathrm{K}$ - left centre of the right housing

$L$ - right centre of the right housing

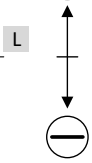

\begin{tabular}{|c|c|c|c|c|c|}
\hline $\begin{array}{c}\text { Key } \\
\text { orientation }\end{array}$ & Load case & $\mathbf{R}_{\mathbf{L} 1}$ & $\mathbf{R}_{\mathrm{L} 2}$ & $\mathbf{R}_{\mathbf{L 3}}$ & $\mathbf{R}_{\mathbf{L} 4}$ \\
\hline $\begin{array}{l}\overline{\widetilde{E}} \\
\stackrel{\bar{E}}{\nu} \\
\end{array}$ & $\begin{array}{l}\text { Preloads } \\
\text { only }\end{array}$ & $\stackrel{\sim}{\sim}$ & 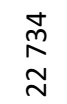 & $\begin{array}{l}\text { J } \\
\text { O } \\
\stackrel{N}{0}\end{array}$ & $\begin{array}{l}\text { n } \\
\stackrel{0}{0} \\
\rightarrow 1\end{array}$ \\
\hline
\end{tabular}




\begin{tabular}{|c|c|c|c|c|c|}
\hline & $\begin{array}{l}\text { Preloads }+ \\
\text { Workload }\end{array}$ & $\begin{array}{l}\text { స̃ } \\
\text { هి }\end{array}$ & $\begin{array}{l}\underset{+}{+} \\
\text { Ð } \\
\underset{1}{+}\end{array}$ & $\begin{array}{l}\stackrel{ }{N} \\
\text { mo } \\
\stackrel{\Gamma}{1}\end{array}$ & 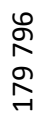 \\
\hline \multirow{2}{*}{ 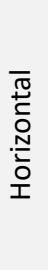 } & $\begin{array}{c}\text { Preloads } \\
\text { only }\end{array}$ & $\underset{\infty}{\infty}$ & 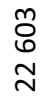 & $\begin{array}{l}-1 \\
0 \\
\stackrel{0}{N}\end{array}$ & $\underset{\sim}{\stackrel{n}{N}}$ \\
\hline & $\begin{array}{l}\text { Preloads }+ \\
\text { Workload }\end{array}$ & \begin{tabular}{l}
$\infty$ \\
\multirow{1}{\sigma}{} \\
న
\end{tabular} & $\begin{array}{l}\underset{N}{N} \\
\text { N } \\
\underset{\sim}{\sim}\end{array}$ & 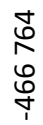 & 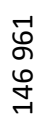 \\
\hline
\end{tabular}

Table 4. Reaction forces - Roll gripped with ball seat - [N]

Reaction forces in bearing were also read and they are presented within this work (see Tab. 4 for Roll gripped with ball seat model).

\subsubsection{Stiffness determination}

Stiffness $\mathbf{k}$ is determined as a workload force $\mathbf{F}$ divided by difference of average value of vertical displacement of the working roll in Preloads only load case and of vertical displacement of the working roll in Preloads + workload load case (see equation 1 ).

$k=\frac{F}{\frac{A_{1}+B_{1}}{2}-\frac{A_{0}+B_{0}}{2}}$

Legend:

$\mathrm{k}$ - stiffness

$\mathrm{F}$ - workload force

$A_{0}$ - vertical displacement of point A - Preloads only load case

$A_{1}$ - vertical displacement of point A - Preloads + workload load case

$B_{0}$ - vertical displacement of point $B$ - Preloads only load case $B_{1}$ - vertical displacement of point $\mathrm{B}-$ Preloads + workload load case

\begin{tabular}{|c|c|c|c|c|c|c|c|c|c|c|c|c|c|}
\hline $\begin{array}{c}\text { Key } \\
\text { orient. }\end{array}$ & Load case & A & B & C & D & E & $\mathbf{F}$ & G & H & I & J & K & $\mathbf{L}$ \\
\hline \multirow{3}{*}{ Verti. } & $\begin{array}{c}\text { Preloads } \\
\text { only }\end{array}$ & -0.01 & -0.01 & -0.01 & -0.01 & -0.01 & 0.00 & -0.01 & 0.00 & -0.01 & 0.00 & 0.00 & 0.00 \\
\hline & $\begin{array}{l}\text { Preloads + } \\
\text { Workload }\end{array}$ & 0.47 & 0.34 & -0.33 & 0.44 & 0.34 & -0.33 & -0.22 & 0.29 & -0.33 & 0.12 & 0.09 & -0.12 \\
\hline & Stiffness & 167 & $\begin{array}{c}\mathrm{kN} / \mathrm{m} \\
\mathrm{m}\end{array}$ & & & & & & & & & & \\
\hline \multirow{3}{*}{ Horiz. } & $\begin{array}{c}\text { Preloads } \\
\text { only }\end{array}$ & -0.01 & -0.01 & -0.02 & -0.01 & 0.00 & -0.01 & -0.01 & 0.00 & -0.02 & 0.00 & 0.00 & -0.01 \\
\hline & $\begin{array}{l}\text { Preloads + } \\
\text { Workload }\end{array}$ & 0.63 & 0.29 & -0.39 & 0.47 & 0.33 & -0.35 & -0.27 & 0.34 & -0.38 & 0.13 & 0.10 & -0.14 \\
\hline & Stiffness & 151 & $\begin{array}{c}\mathrm{kN} / \mathrm{m} \\
\mathrm{m}\end{array}$ & & & & & & & & & & \\
\hline
\end{tabular}

Table 5. Displacement values [mm] and stiffness [kN/mm] - Roll gripped with ball seat

\subsubsection{Results and its discussion}

Next table (see Tab. 6) summarize results of stiffness for all four compared approaches how to mount the working roll within the machine stand.

\begin{tabular}{|c|c|c|c|c|c|}
\hline & & $\begin{array}{c}\text { Square } \\
\text { cross. } \\
\text { sect. }\end{array}$ & $\begin{array}{c}\text { Circle } \\
\text { cross. } \\
\text { sect. }\end{array}$ & $\begin{array}{l}\text { Grip } \\
\text { cone }\end{array}$ & $\begin{array}{l}\text { Grip } \\
\text { ball }\end{array}$ \\
\hline \multirow{3}{*}{ 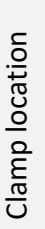 } & Upper & 196 & 66 & & \\
\hline & Vertical & 222 & 106 & & \\
\hline & Bottom & 231 & 89 & & \\
\hline \multirow{2}{*}{ 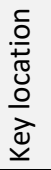 } & Horizontal & & & 148 & 167 \\
\hline & Vertical & & & 137 & 151 \\
\hline
\end{tabular}

Table 6. Comparison of stiffness $[\mathrm{kN} / \mathrm{mm}]$

Results discussion:
- For all design proposals, the stiffness is dependent on the position of clamp or key in which it is loaded.

- The highest stiffness was found for roll mounted in an open seats square cross section variant.

- The variant with the working roll gripped with cone or ball seats shows almost similar values of stiffness for the horizontal or vertical position of the pen. (There is a clearance of $0.05 \mathrm{~mm}$ within the simulation).

- The stiffness of the variant with ball seat is slightly higher (i.e. better) than for variant with cone seat.

- Inner bearings are more loaded than outer.

\section{CONCLUSIONS}

The work aim was to compare different design proposals and to find variant with high stiffness. Comparison of design variants was performed on simplified model of rolling machine with only upper working roll. Proposed bearings were simplified to a spring model.

Overall the best variant in a stiffness point of view is a variant with square cross section. It is a present variant. But this variant is the worst for the production. Coaxiality of the working roll and 
support shaft is very doubtful. With real machine coaxiality is set by inserting thing plates into connection. It is not precise and also very time demanding.

The result is that variants with gripper roll are more than equivalent to variants with seat and clamp due to its symmetrical behaviour during rotation. Their big advantage is hidden in guaranteed coaxiality of the working roll and its support roll. Variants with clamp and seat are highly sensitive to its position (see stiffness results for circle cross section variant).

Weak property of variant with gripped roll is in unequal supports shafts stiffness. It is due to retractable shaft and its slide bearing guide.

\subsection{Proposals for next research}

There are several proposals for next research.

1. Full model. To improve identity between model simulation and real machine behaviour it is possible to simulate whole model. Especially the bottom working roll is important due to its position adjustment and guided housings in the stand.

2. Grip force. The working roll is gripped and pressed by preload force. What is the influence of different preload force? Will higher force leads to stiffer grip or will it deform the stand?

3. Bearings. Bearings stiffness influence stiffness of whole machine. Inner bearings could be doubled as their load is higher. Also the prise of bearing must be considered.

4. Retractable shaft. The weak part of the design is a retractable shaft. Loaded shaft tilts within its slide guide. Length, diameter or position of guide could be checked.

\section{ACKNOWLEDGMENTS}

This article was done by financial support SGS-2019-001 of University of West Bohemia.

\section{REFERENCES}

[Baoshou 2012] Baoshou, S. et al. Patent CN102553928A: Roll system of replaceable-roll type cross wedge rolling mill (in Chinese). China National Intellectual Property Administration, 2012
[Bartosek 2011] Bartosek, P. SOUTION TECHNOLOGY OF „TOOL SEGMENT" PART IN FIRM SMERAL BRNO A. S. (in Czech). Bachelor thesis. Brno University of Technology, Faculty of Mechanical Engineering. 2011. Supervisor: Ing. Milan Kalivoda

[Domazet 2014] Domazet, Z. et al. Failure analysis of rolling mill stand coupling. In: Engineering Failure Analysis, 2014, Vol.46, ISSN 1350-6307 DOI: 10.1016/j.engfailanal.2014.09.002

[Hladky 1969] Hladky, V. Patent 133255: Cross Wedge Rolling Mill (in Czech). Brno: Urad pro patenty a vynalezy, 1969.

[Hladky 1991] Hladky, V. and Prokes, J. Patent 271380: Rolling Machine with Quickly Exchangeable Working Rolls (in Czech). Brno: Federalni urad pro vynalezy, 1991.

[Hlavac 2018] Hlavac, J. et al, J. ULS - stiffness of the roller embedding. FV10578-E2 - 2018. Plzen: University of West Bohemia, 2018.

[Liping 2020] Liping, W. et al. Optimization design of a novel Xtype six-high rolling mill based on maximum roll system stiffness. In: PLOS ONE, 2020, Vol.15, No.2, ISSN 1549-1277 DOI: 10.1371/journal.pone.0228593

[Malinkin 1972] Malinkin, V.S. and Nikolsky, L.N. Patent SU459292: Tool for cross wedge rolling (in Russian). Moscow: Rospatent, 1972.

[Meingast 1969] Meingast, K. and Koutsky, M. Patent 130874: Sliding bearing of rolling mill rolls (in Czech). Plzen: Urad pro patenty a vynalezy, 1969.

[Normaley 1973] Normaley and Volgogradsky. Patent SU388820: Device for cross-wedge rolling of cylindrical parts (in Russian). Moscow: Rospatent, 1973.

[Pater 2014] Pater, Z. Cross-Wedge Rolling. In Comprehensive Materials Processing; Button. S. T., Ed. Elsevier Ltd., 2014, Vol.3, pp 211-279, ISBN 9780080965321

[Tomczak 2018] Tomczak, J. et al. THE FLAT WEDGE ROLLING MILL FOR FORMING BALLS FROM HEADS OF SCRAP RAILWAY RAILS. In: Archives of Metallurgy and Materials, 2018, vol.63, No.1, pp 5-12, ISSN 17333490, DOI: $10.24425 / 118901$

\section{CONTACTS:}

Doc. Ing. Jan Hlavac, Ph.D.

University of West Bohemia, Faculty of Mechanical Engineering, Department of Machine Design

Univerzitni 2732/8 ,Plzen, 301 00, Czech Republic

+420 377638 217, jhlavac@kks.zcu.cz 